\title{
Analysis of Status Quo of Politics Course in Colleges and Universities with Philosophical Review
}

\author{
Mingyu Han \\ Liaoning Jianzhu Vocational College, Shenyan, Liaoning, 111000
}

Keywords: Status Quo, Politics Course in Colleges and Universities, Philosophical Review

\begin{abstract}
At present, the research on ideological and political theory teaching in colleges and universities mainly focuses on the main problems existing in the teaching of ideological and political theory and how to solve these problems. Under the heavy social pressure on the high expectation of the teaching of ideological and political theory, the researchers pay more attention to the internal factors that affect the teaching of the ideological and political theory than the external factors. In studying the current situation of the teaching of ideological and political theory, even without any choice, all the problems in reality are included in the scope of ideological and political education, which leads to the "pan-problem" of the research on the ideological and political theory education from Marxism philosophical perspective. The research paradigms and theoretical perspectives in this theory will provide a brand new perspective and important enlightenment for the future research on the current situation of ideological and political theory teaching in colleges and universities.
\end{abstract}

\section{Introduction}

The strong concern with realistic issues is an important characteristic that distinguishes Marxist philosophy from any other philosophical theory. Marxist philosophy is logically integrated under the direction of social practice and is generated from paying attention to, researching and solving the ever-changing social reality [1].

The course of ideological and political theory has always been a required course for college students, which is highly valued by the state. Starting from the research paradigm of problem awareness and studying the current situation of the teaching of ideological and political theory, it is not hard to find that the reality is not optimistic. From the current situation of the course of ideological and political theory, there is still a gap between the teaching effect of the course and the duties it shoulders. A few students showed a negative attitude toward the course study. The concrete manifestation is that one is absent, and the other is that the lectures are not serious. All of these make it difficult for Ideological and Political Theory Course to achieve the desired effect of ideological and political education for students. Although there are many reasons for the unsatisfactory teaching effect of ideological and political theory courses, it is an indisputable fact that minority students do not agree with the teaching of ideological and political theory courses. The causes of the weak teaching effectiveness of ideological and political theory courses include: "Under the influence of social utilitarianism, a few students think that ideological and political theory courses are of no use to their own development. Even some teachers of ideological and political theory and teachers of specialized courses, School leaders also hold the view that students do not like this course and the more factors should be that they do not understand the practical usefulness of this course [2]. Hence, although most students think the ideological and political theory class is important and necessary, however, at the same time, most college students think that the purpose of studying the course of ideological and political theory is to hope for the usefulness of their future work. This shows that the contemporary college students have obvious practical and utilitarian tendencies in their political orientation. Teaching overemphasizes the theoretical, systematic and social practice a serious lack of links. Although in order to improve the effectiveness of the teaching of ideological and political theory, some teachers from the teaching content, methods and means of teaching and other aspects of reform and innovation, but due to funding 
constraints and other issues, never jump out of teaching overemphasis on the theory Systematic stereotypes, social reality Serious missing part of the practice, thereby reducing the students interest in learning.

Problem awareness is a common dimension of thinking in academic research. If all the problems in reality are indiscriminately included in the scope of Marxist philosophical research, it will undoubtedly lead to pan problems in the study of Marxist philosophy. Similarly, in the course of studying the current situation of the teaching of ideological and political theory, if all the problems in the reality are indiscriminately included in the scope of the ideological and political education, it will undoubtedly lead to the generalization of the research on the ideological and political theory education. At present, the research on the current situation of the teaching of the ideological and political theory in our country has become a trend of pan-problem. The concrete manifestation is that in order to improve the effectiveness of the teaching of ideological and political theory, it contributes to the cultivation of personnel with higher cultural and ideological qualifications in colleges and universities. The researchers mainly focus their improvement on the improvement of teaching methods, and pay attention to the internal factors of ideological and political education, such as content, methods, channels and approaches. And less attention to the ideological and political education of external factors, such as the social and psychological environment, the state of social mentality, the impact of the system or related regulations, the party's style of work and political situation. The one-sidedness of this perspective will inevitably lead to the teaching of ideological and political theory as a panacea for cure. The ideological problems appearing in the students boil down to the ideological and political theory courses and ideological and political theory course teachers. This is not realistic. The reason why this happens is directly related to the fact that the entire real society has too much expectation on the teaching of ideological and political theory [3].

\section{The Role of Positioning Is Not Accurate and the Value of the Evaluation Criteria Set Too High}

The Marxist philosophy that focuses on the study of realistic problems from the consciousness of the problem is to reveal and expose the differences and antagonisms between the reality and the ideal, the reality and the existence, and it potentially contains an ideal and the criterion of value evaluation Set, that is, the basis of value norms set. The setting of the basis of value norms as a tentative direction for the change of fact shows the value regulating effect. From the perspective of problem consciousness, the status quo of ideological and political theory teaching can potentially contain a precondition of ideals and value evaluation criteria. This precondition provides the normative basis and value evaluation criteria for the study of current ideological and political theory teaching, it is precisely through the establishment of a normative foundation that the research on the status quo of ideological and political theory courses has a critical nature. Therefore, without the setting of the basis of the value norms, starting from the problem consciousness to study the status quo of the course of ideological and political theory also lost the premise and foundation of existence. Ideals and values as the basis for normative norms and functions as a diagnosis and guidance, the former has become the standard of critical research in ideological and political theory teaching, that is, the criterion of the establishment of poor effectiveness; the latter has become a hope to change the ideological and political theory foundations and requirements of teaching status. The setting of ideal and value evaluation criteria is a search for new possibilities. Although this exploration is rooted in reality, it requires surpassing existing defects and incompleteness. As a quest for a better and fuller state of the future, it at least shows that there are no problems identified in the current state in the future. The ideal goal setting is based on its beyond the present state, to provide people with judgments and grasp the existing conditions beyond the value of the criteria and it as a prerequisite for a variety of different values and the goal of a different analysis of the phenomenon shows that There are all the limitations of the limited existence of defects and deficiencies [4]. Starting from the Paradigm of Problem Consciousness, looking at the status quo of teaching of ideological and political theory, it is not difficult to find that the expectation of social 
teaching of ideological and political theory is too high. Most of the people think that ideological and political theory teaching should have its own merits the actual effect of the battle, that is, only through the teaching of ideological and political theory can solve all the ideological problems of students. However, from the practical effect of teaching, the ideological and political theory class fails to reach the high expected value of society well, and it is just such an overly high goal of society that makes the teaching of ideological and political theory course embarrassed.

As the main front and main channel of ideological and political work in colleges and universities, the teaching of ideological and political theories should play its important role in ideological and political education for college students. However, this role can not be unlimitedly magnified. And school education itself is an integrated system, not just the ideological and political theory teaching. The main body of the ideological and political education of college students mainly include; party and government cadres and CYL cadres, ideological and political theory classes and teachers of philosophy and social science classes, counselors and class teachers. It is clear that the work undertaken by each of these teams is not just a teaching of ideological and political theory. Moreover, the realization of the value of the course of ideological and political theory has the characteristics of indirectness, process and long-term, and the function of ideological and morality has been realized through the transformation of human practice. In the meantime, after a series of intermediate links, a longer Process, the ultimate effect of their learning will not be as professional courses, especially practical courses, can immediately pay off, do not learn the harm will not be quickly apparent in a short time to improve the moral quality of students and the use of Marx The position, viewpoints, and methods of analyzing and solving problems can not be resolved in a single step. Obviously, it cannot be solved by the ideological and political theory courses alone.

We should take college students, like dislikes, dissatisfaction, dissatisfaction, acceptance as an important measure to evaluate the success of classroom teaching of ideological and political theory, with sound self as the value orientation of ideological and political education and ideological self as ideological and political education High pursuit. However, the ideological and political theory class as a master key, once the students have problems attributed to the ideological and political theory class and ideological and political theory of the teacher's view is not correct, only through the teaching of ideological and political theory, It is unrealistic and impossible to develop all our college students into a determined Marxist and a qualified builder of the socialist cause.

\section{The Practice of Teaching Is the Key, the Inevitable Requirement of Human Existence}

Practice is the way of human existence, and is the fundamental reason for the existence and development of human beings. To practice as the starting point, Marxist philosophy holds that man is not an outsider or an eternal being with some divinity. Man is a historical product, and its own formation process is objective. People create the environment. Likewise, the environment also creates people. The historical, continuity and two-way objectification of practice shows that human being is a kind of person, that is, man is not an immutable existence. He is produced, exists and developed in practice. Practice is the root cause of self-perfection and development of man himself.

Ideological and political education in the final analysis is a man's work, and practice is the root cause of human existence and development. Therefore, in essence, ideological and political education activities should be practiced. In the West, moral philosophy or ethics is the philosophy of practice. Moral philosophy is called practical philosophy because it studies practice or behavior. Practice is the root and motivation of individual moral formation and development. Practical activity is the main way of individual self-education. Practical activity is the ultimate goal of moral education value realization. Aristotle believes that the purpose of ethics is not knowledge but practice, and in practice things are not aimed at the theory and knowledge of each subject, but more importantly at the practice of them. It is not enough to know only virtue, but also to apply or somehow make us good. It can be said that practical teaching is an important way to improve the effectiveness of the teaching of ideological and political theory. The CPC Central Committee and the State Council, on further strengthening and improving ideological and political education of college students - clearly pointed out that social practice is an important part of ideological and 
political education for college students, to promote college students understand the community, understand the national conditions, growth, talent, social commitment, perseverance, cultivate character, enhance social responsibility has an irreplaceable role. Needless to say, in theory teaching, if only from theory to theory, inevitably abstract, boring, combined with the inherent directional thinking, it is difficult to mobilize the enthusiasm of students learning, initiative. Therefore, the teaching of ideological and political theory takes the path of practical teaching, which is an effective way to omit teaching effectiveness of ideological and political theory from the overall situation, strategy and fundamentals. To strengthen the teaching of practice, students should be organized to participate in social practice. Only in this way can we establish the long-term mechanism of practical teaching of ideological and political theory course, which is the key to effectively improve the teaching effectiveness of the ideological and political theory course [5].

First of all, we must set the outline around the teaching objectives, stipulate the hours, credits, provide the necessary funds to strengthen the organization and management, so that students go out of school, to the ideological and political theory of social teaching, big class, to go, so that students participate in various Community service and social service. It provides opportunities for college students to connect with the society so that students can digest, comprehend and sublimate the theoretical knowledge they have learned in class so as to cultivate their sense of social responsibility and social morality and civic awareness.

Second, pay attention to the use of patriotic education base and student associations organizations of political education and moral education of college students. These places not only reflect the achievements of our country's material and spiritual civilization, but also serve as important bases and vivid teaching materials for college students in our country's political system and values education. Give play to the role of the second class, the Communist Youth League, and student associations, support and guide the student associations to carry out educational activities and deepen the understanding of the contents of the ideological and political theory courses in practical activities.

Finally, to further strengthen the ideological and political theory teaching team and the school student work team, school party and government cadres and Communist Youth League cadres, counselors and teachers and other cooperation between the class, give full play to their role in student management. We must work hard to closely integrate the ideological and political theories with the ideological and political work of various departments in schools so as to enhance the overall effect of the education in ideological and political theory courses.

\section{Conclusions}

The ideological and political education in colleges and universities is a complex systematic project, and the factors influencing the effectiveness of ideological and political education in colleges and universities are also many. In order to make the ideological and political education of college students have a good social effect, the key lies in the ideological and political theory of classroom teaching reform and innovation, based on the further strengthening of practical teaching links, attention in many aspects, multi-sectoral linkage, multi-level promotion, in order to receive the desired effect.

\section{References}

[1] Chen Chuming. The Internalization of Problem Consciousness and Its Effective Trigger - A Case Study of Ideological and Political Theory Course in Colleges and Universities [J]. Heihe Academy of Sciences. 2013 (07).125

[2] Yi Yong clothing. In the new era of ideological and political education in colleges and universities to strengthen the sense of "problem awareness" of the meaning[J]. Heilongjiang Education (Higher Education Research and Evaluation. 2016 (11).58

[3] Xie Xiwei. Construction of "Problem Consciousness" of Graduate Students in Ideological and 
Political Theory Teaching [J]. Journal of Jiamusi Vocation College. 2015 (04).78

[4] Han Fengmei. Problem-oriented college ideological and political theory teaching [J]. Education and Careers. 2015 (27). 45

[5] Wang Weijiang. Exploration of Teachers' Problem Consciousness in Ideological and Political Theory Teaching [J]. Arts \& Social Navigation (Late). 2014 (09). 56 